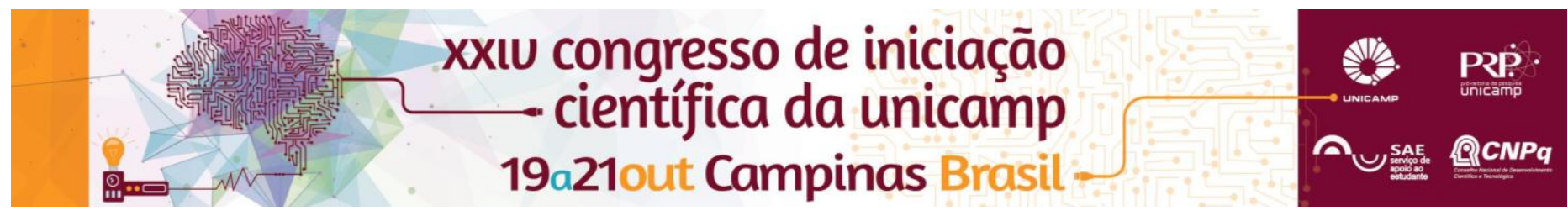

\title{
O Trabalho Docente e o Currículo de Geografia do Estado de São Paulo: hegemonia, discursos e autonomia
}

\author{
Gabriela F. Jordão; Orientador: Prof. Dr. Rafael Straforini
}

\begin{abstract}
Resumo
Esta pesquisa busca verificar, refletir e discutir como os discursos curriculares oficiais, mais especificamente do atual Currículo de Geografia do Estado de São Paulo e seus cadernos (do aluno e do professor), são trabalhados pelos docentes no ensino médio da rede paulista de educação, a fim de evidenciar os contextos de significação ocorridos nessa micro escala da sala de aula, que vão para além do currículo prescritivo, que mesmo ainda considerado prática discursiva hegemônica de acordo com a teoria do discurso de Laclau, deixa brechas para contradições e ambivalências em determinados temas/conceitos, possibilitando a subversão e/ou recontextualização desses pela autonomia do trabalho docente.
\end{abstract}

Palavras-chave: Currículo de Geografia do Estado de São Paulo, ensino de Geografia, autonomia docente.

\section{Introdução}

No intuito de problematizar o "São Paulo Faz Escola" e a proposta curricular produzida por esse programa, "O Currículo do Estado de São Paulo", que tem gerado polêmica e descontentamento aos docentes da rede paulista de educação - visto a perda de autonomia destes frente a um currículo único e prescritivo, no qual se desconsidera a experiência de 240 mil docentes a fim de garantir uma base comum de conhecimento e competências para os 4 milhões de estudantes, aos quais despreza seus cotidianos e anula a grande diversidade existente no estado de São Paulo, transformando o ensino-aprendizagem em algo sequencial, com conteúdo e tempo determinados, suprimindo a possibilidade de criação na sala de aula pelo corpo docente, - este trabalho indaga-se sobre a limitação das escolas e professores à sua capacidade, ou não, de implementar adequadamente as orientações curriculares oficiais, objetivando expor os usos dos cadernos - os popularmente chamados "caderninhos" do professor e do aluno -, principais materiais gerados pelo currículo em tela, evidenciando os limites de se adotar fielmente tal material $e$ as possibilidades de reinterpretação e articulação que podem ocorrer de acordo com os contextos e experiências presentes na escola e que foram ignorados na produção deste documento curricular.

\section{Resultados e Discussão}

Pautados na teoria do discurso de Ernesto Laclau, apesar de considerarmos o currículo em questão como uma prática discursiva hegemônica, vemos que este é resultado de articulações de cadeias de diferenças em benefício de uma cadeia de equivalência de grupos que almejam e estão no poder, e que de certa forma, consideram tal documento um importante instrumento de controle social, ainda que se trate de um discurso provisório e contingente, visto que torna-o objeto de disputa entre grupos particulares, que "competem entre si para dar temporariamente a seus particularismos uma função de representação universal" (LACLAU, 2011, p. $66)$, ou seja, de hegemonia.

Dessa forma, percebe-se a existência de uma grande pluralidade de correntes epistemológicas da geografia no currículo em questão, reflexo do processo de negociação e conflito entre diferentes sujeitos e suas particularidades que compõem a comunidade disciplinar que gerou 0 currículo de geografia do estado (COSTA e LOPES, 2016). Assim, esse documento é resultado de uma comunidade heterogênea, carregada de divergências e embates internos, que negociam a fim de atuar politicamente e introduzir suas demandas na cadeia articulatória.

A partir disso, procuramos por meio da pesquisa etnográfica, que "permite a investigação dos efeitos das políticas em contextos locais, favorecendo situar os discursos em táticas e relações de poder específicas" (LOPES, 2005, p. 56), valorizar o cotidiano escolar e a autonomia docente (CONTRERAS, 2012), no intuito de observar os usos feitos dos materiais foco dessa pesquisa, os caderninhos. Para tanto, acompanhamos dois professores da rede educacional paulista, com o objetivo de evidenciar as práticas que fogem ou confluem com as definições curriculares.

\section{Conclusões}

Levando em conta os acordos da comunidade disciplinar na formulação do currículo de geografia, percebemos brechas, contradições e ambivalências em determinados conceitos e temas curriculares, o que caracterizamos, de acordo com Laclau, como significantes vazios ou flutuantes, visto a contingencialidade nos processos de significação. Acreditamos que essa indefinição possibilita a abertura dessa cadeia para interpretações por parte do trabalho docente, mostrando que o currículo está para além de sua produção, apresentando espaço para a autonomia do professor, de acordo com suas experiências e práticas. Por conseguinte, continuamos as observações em sala de aula com o propósito de mostrar e exemplificar esse processo.

\section{Agradecimentos}

Agradeço aos membros do APEGEO e ao meu orientador pelas discussões. Aos professores da rede paulista de ensino que abriram suas salas de aula para as observações. E à FAPESP pela bolsa concedida.

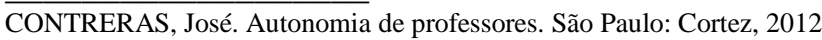
COSTA, Hugo Heleno Camilo; LOPES, Alice Ribeiro Casimiro. A Geografia na política de currículo: quando a integração reafirma a disciplina. ProPosições [online]. 2016, vol.27, n.1.

LACLAU, Ernesto. Emancipação e Diferença. Rio de Janeiro: EdUERJ, 2011 LOPES, Alice Casimiro. Política de currículo: Recontextualização e Hibridismo. Currículo sem Fronteiras, v.5, n.2, pp.50-64, Jul/Dez 2005. 